$-.2 e$

Connecticut

Agricultural

Experiment

Medicinal Herb

Station,

Trial 1996

New Haven

BY LAURA J. W. BUTTERFIELD

Bulletin 943

March 1997 

WITH CARE

University of Connecticut Libraries

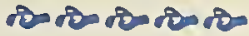

The Connecticut Agricultural Experiment Station is an Equal Opportunity, Affirmative Action Employer. Persons with disabilities who require alternate means of communication of program information should contact the Station Editor at the following:

(203) 789-7223 (voice), (203) 789-7232 (fax), or caesadmn@caes.state.ct.us (e-mail). 


\title{
Medicinal Herb Trial 1996
}

\author{
BY LAURA J. W. BUTTERFIELD
}

\section{INTRODUCTION}

Expanding interest in alternative medicine has increased the market for medicinal herbs throughout the United States. Today herbs are found not only in health food stores, but in the pharmacy sections of drugstores and supermarkets. Mailorder sales are also expanding. According to Natural Foods Merchandiser, a trade magazine for the health-food market, overall sales of medicinal herbs have been increasing by $18 \%$ annually, on average. Monica Emerich of New Hope Communications reports that the 1994 market for medicinal herbs in health food chain stores alone was valued at $\$ 1.32$ billion, and in 1995 organically grown herbs became the top growth category of the entire natural products market with a $33 \%$ increase in sales (Mergentime and Emerich, 1996). With over 380,000 acres of farmland, Connecticut is in a position to take advantage of this burgeoning market (National Agricultural Statistical Service, 1996). Growers of medicinal herbs, in particular herbs certified as organically grown, are in high demand by wholesale distributors and supplement manufacturers.

Our trial was designed to determine the suitability of some of these crops to the soil and climate conditions found in Connecticut. This assessment includes yield data and an analysis of active principles in field-grown samples compared to those sold over-the-counter. The first of these two objectives from the first year harvest are covered in the following text and graphics. The second is underway and will be reported at a later date.

\section{GENERAL METHODS AND MATERIALS}

\section{Seed Germination}

Eleven companies (Table 1) supplied seeds of twelve herb genera. The exact seed cultivar of each is specified in Table 2. Germination rates were determined for seeds from nine of the companies. Seeds from the remaining two companies arrived too late to test germination in the greenhouse. Therefore, only the chamomile and borage seeds from these two companies were included in the trial, since these two species were directly field-sown. Seed lots of each species will be referred to as "samples" in the following discussion.

We evaluated germination rates by sowing 36 to 72 seeds per sample in flats containing potting soil (ProMix) according to package directions. When no instructions were provided, the general protocol from other packages was followed. Because of the wide variety of species, specific requirements of each species were accommodated as best as possible in the greenhouse. This included the use of supplemental halogen lighting for species requiring light for germination, and maintenance of an average $72 \mathrm{~F}$ ambient temperature. Specific methods for each sample are described in the discussion of each species below.

\section{Field Planting}

Up to ten plants per sample, each plant representative of the average size, were transferred from the flat to 4.5 inch square or 5 inch diameter round plastic pots. Plants were allowed to grow for up to a month in the greenhouse, with biweekly fertilization using Hoagland's solution (Hoagland and Amon, 1950). These were transferred to a cold frame on May 14,10 days before field planting.

Analysis of a composite soil sample indicated that the herb field plot was a Wactaugh sandy loam ( $\mathrm{pH} 5.9$ ) with medium organic content and low nitrogen. Prior to planting, fertilizer (10-10-10) and lime were amended into the soil at $10 \mathrm{lb}$. per 1000 sq. ft. and $75 \mathrm{lb}$. per 1000 sq. ft., respectively. For the perennials and calendula, sheets of $10 \mathrm{ft}$. wide black landscape cloth (Agway) were laid down and holes cut at 1.75-2 ft. spacing in rows spaced $2 \mathrm{ft}$. apart. These plants were transferred into the field on May 24. 
Seeds of chamomile and borage (both annuals) were planted within the next week in areas without landscape cloth. The plot received full sun. Sprinklers were set up for watering until the plants became established.

The open area in the landscape cloth around the seedlings was hand weeded. Walkways between species were sprayed twice toward the end of the season with glyphosate (Monsanto). Any weeds appearing between the rows of plants were hand-pulled. Hay was used to cover the landscape cloth when it began to break down in late July.

\section{Harvesting and Drying}

All perennial species were harvested lightly in 1996 so as to assure that the plants were well established before winter. Due to their variable growth rates, leafy perennials were harvested at different times. Most were harvested just at the onset of flowering, a procedure recommended by herbalists purportedly to maximize phytochemicals in the foliage (Dobelis, 1986). Sharp hedge clippers were used to top the plants, cutting them parallel to the ground 4-8 inches above the soil line. Bolt-type flower stalks, found in certain species, were cut at ground level and the remaining foliage was left to help rejuvenate the plants. Leafy annuals were cut at the soil line. Flowers from annuals were harvested at 3-6 day intervals over the flowering period to encourage continual flower induction. Specific details on each species are found below.
Harvested material from each sample plot was pooled and dried. Drying was done in one of two ways: 1) in an oven set at $45-60 \mathrm{C}$ for 3-14 days; or 2 ) in the greenhouse at ambient temperatures (75-1 10F) for up to 3 weeks. In either case, material was dried to just crispness so as to retain the original coloring and most of the essential oils and volatiles (Dobelis, 1986). Samples were weighed either on an analytical balance (for small amounts) or on a large capacity balance. Subsamples were taken from the composite mixture, placed into air-tight plastic bags, and labeled for future analysis

\section{CONCLUSIONS}

Medicinal herbs are suitable for cultivation in Connecticut. Interested growers are strongly encouraged to establish contacts, some of which are listed in Table 4, prior to capital outlay. For example, staff at New Mexico State University have completed a cost analysis for producing the final dried herb commodity from fresh field-grown plants. These data will prove valuable to Connecticut growers.

The data in this bulletin are meant to serve as a general guide on how these crops will perform in Connecticut climate and soil conditions. This information is the result of one year of observations and more detailed investigations into the cultivation of these and other similar species are appropriate.

Table 1. Participating seed companies.

\begin{tabular}{|c|c|c|c|c|c|c|c|}
\hline Company & Address & City & State & Zip & Phone & Symbol $^{1}$ & $\begin{array}{l}\text { Packed } \\
\text { for }^{2}\end{array}$ \\
\hline Companion Plants & 7247 N Coolville Ridge R & Athens & $\mathrm{OH}$ & 45701 & $614-592-4643$ & $\mathrm{CP}$ & '96 \\
\hline Comstock, Ferre \& Co. & 263 Main Street & Wethersfield & CT & 06109 & $860-571-6590$ & $\mathrm{CFC}$ & '95 \\
\hline Goodwin Creek Gardens & PO Box 83 & Williams & OR & 97544 & $800-846-7359$ & GCG & ‘96 \\
\hline Horizon Seeds & PO Box 69 & Williams & OR & 97544 & $503-846-6704$ & HS & '96 \\
\hline Johnny's Selected Seeds & 310 Foss Hill Road & Albion & ME & 04910 & $207-437-4301$ & JSS & '96 \\
\hline Nichol's Garden Nursery & 1190 Pacific Coast Hwy & Albany & OR & 97321 & $541-928-9280$ & NGN & ‘96 \\
\hline Pinetree Garden Seeds & Box 300 & New Gloucester & $\mathrm{ME}$ & 04260 & $207-926-3886$ & PTGS & ‘96 \\
\hline Redwood City Seed Co. & PO Box 26 & Redwood City & $\mathrm{CA}$ & 94064 & $415-325-7333$ & RS & ‘96 \\
\hline Shepard's Garden Seeds & 30 Irene Street & Torrington & CT & 06790 & $860-482-3638$ & SGS & '96 \\
\hline The Thyme Garden & 20546-H Alsea Hwy & Alsea & $\mathrm{OR}$ & 97324 & $541-487-8671$ & TG & NA \\
\hline Well-Sweep Herb Farm & 317 Mt. Bethel Road & Port Murray & NJ & 07865 & na & WS & '96 \\
\hline
\end{tabular}

'The abbreviation by which the company is referred throughout this document.

${ }^{2}$ Some packages within a sample lot did not have "packed for" dates. These were assumed to be packaged for the same year as others within the same lot. NA = no "packed for" dates were indicated on any package in the sample. 
Table 2. Herb species, common names, and seed donors.

\begin{tabular}{|c|c|c|c|c|}
\hline Latin name & Common name & variety/cultivar & Min. Germ.' & Sources \\
\hline Borago officinalis & borage & no designation & JSS, WS - 75 & all 11 \\
\hline Calendula officinalis & pot marigold & $\begin{array}{l}\text { no designation } \\
\text { Pacific Beauty Mix } \\
\text { Kablouna } \\
\text { Bon Bon Mix }\end{array}$ & JSS - 75 & $\begin{array}{l}\text { CP, CFC, GCG, HS, TG } \\
\text { JSS, PTGS } \\
\text { SGS } \\
\text { NGN }\end{array}$ \\
\hline Echinacea purpurea & purple coneflower & $\begin{array}{l}\text { Starlight } \\
\text { no designation }\end{array}$ & JSS - 60 & $\begin{array}{l}\text { SGS } \\
\text { CP, GCG, HS, JSS, NGN, PTGS, TG }\end{array}$ \\
\hline E. angustifolia & prairie coneflower & no designation & & HS \\
\hline Hyssopus officinalis & hyssop & no designation & JSS - 65 & CP, CFC, GCG, HS, JSS, NGN, PTGS, TG \\
\hline Matricaria recutita & German chamomile & no designation & JSS - 65 & CP, CFC, GCG, HS, JSS, NGN, PTGS, RC, SGS, TG \\
\hline Marrubium vulgare & horehound & $\begin{array}{l}\text { White } \\
\text { no designation }\end{array}$ & JSS - 60 & $\begin{array}{l}\text { CFC, TG } \\
\text { CP, GCG, HS, JSS, NGN }\end{array}$ \\
\hline Melissa officinalis & lemon balm, melissa & no designation & JSS - 65 & CP, CFC, HS, JSS, PTGS, SGS, TG \\
\hline Mentha & $\operatorname{mint}$ & Common mint & & PTGS \\
\hline M. spp. & unknown mint ${ }^{2}$ & Peppermint $^{2}$ & & $\mathrm{CFC}, \mathrm{TG}$ \\
\hline M. X spicata & spearmint & Spearmint & & NGN \\
\hline Monarda didyma & $\begin{array}{l}\text { bee balm, } \\
\text { bergamot }\end{array}$ & $\begin{array}{l}\text { no designation } \\
\text { Panorama Mix }\end{array}$ & JSS - 50 & $\begin{array}{l}\text { GCG, HS, NGN, TG } \\
\text { JSS }\end{array}$ \\
\hline Nepeta cataria & catnip & no designation & JSS - 50 & CFC, GCG, HS, JSS, NGN, PTGS, SGS, TG \\
\hline Tanacetum parthenium & feverfew & $\begin{array}{l}\text { White Wonder } \\
\text { Double Flowered } \\
\text { Single } \\
\text { Golden Ball } \\
\text { no designation }\end{array}$ & JSS - 60 & $\begin{array}{l}\text { SGS } \\
\text { GCG } \\
\text { TG } \\
\text { PTGS } \\
\text { CP, HS, JSS }\end{array}$ \\
\hline T. cinerarifolium & pyrethrum & Pyrethrum & & GCG \\
\hline Valerania officinalis & valerian & no designation & JSS - 50 & HS, JSS, NGN, TG \\
\hline
\end{tabular}

Min. Germ. = minimum germination percentage printed on the seed package.

${ }^{2}$ Peppermint (Mentha x piperita) is a sterile hybrid and does not produce seed, therefore the species of the seed in these packages is unknown. 
Table 3. Planting and yield estimates for dried herbs.

\section{Latin Name}

\section{Variety/}

cultivar

Annual/
perennial

\section{Plant Out/ harvest date}

\begin{abstract}
Days
\end{abstract}
in field
Dried

Form
Est. average

Yield/Acre,

lb. Dry Weight $+\mathrm{SD}^{1}$

\begin{tabular}{|c|c|c|c|c|c|c|}
\hline Borago officinalis & no designation & $A$ & May 30/Aug 27 & 89 & herb & $5,799 \pm 1,603$ \\
\hline Calendula officinalis & $\begin{array}{l}\text { Bon Bon } \\
\text { Pacific Beauty Mix } \\
\text { Kablouna } \\
\text { no designation }\end{array}$ & $\begin{array}{l}\text { A } \\
A \\
A \\
A\end{array}$ & $\begin{array}{c}\text { May 24/Sept } 11 \\
\text { “ } \\
\text { “ } \\
\text { “ }\end{array}$ & $\begin{array}{l}104 \\
.4 \\
. \\
.\end{array}$ & $\begin{array}{l}\text { whole flower }{ }^{2} \\
\text { “ } \\
\text { “ }\end{array}$ & $\begin{array}{c}425 \\
513 \pm 147 \\
495 \\
349 \pm 90\end{array}$ \\
\hline Echinacea purpurea & $\begin{array}{l}\text { Starlight } \\
\text { no designation }\end{array}$ & $\begin{array}{l}\mathrm{P} \\
\mathrm{P}\end{array}$ & $\begin{array}{c}\text { May 24/Oct } 1 \\
\text { c } \\
\text { not harvested }\end{array}$ & $\begin{array}{c}130 \\
130 \\
-\end{array}$ & $\begin{array}{l}\text { herb } \\
\text { "s } \\
\text { root }\end{array}$ & $\begin{array}{c}1,350 \\
1,641 \pm 991\end{array}$ \\
\hline E. angustifolia & no designation & $\mathrm{P}$ & not harvested & - & root & \\
\hline Hyssopus officinalis & no designation & $\mathrm{P}$ & May 24/July 19 & 56 & herb & $457 \pm 133$ \\
\hline Matricaria recutita & no designation & $A$ & May $30 /$ Sept 16 & 105 & whole flower & $496 \pm 236$ \\
\hline Melissa officinalis & no designation & $\mathrm{P}$ & May $24 /$ Oct 1 & 130 & herb & $2,946 \pm 1,175$ \\
\hline Marrubium vulgare & $\begin{array}{l}\text { White } \\
\text { no designation }\end{array}$ & $\begin{array}{l}\mathrm{P} \\
\mathrm{P}\end{array}$ & 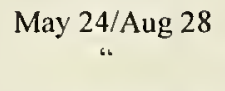 & 96 & $\begin{array}{l}\text { herb } \\
\text { " }\end{array}$ & $\begin{array}{l}5,087 \pm 572 \\
3,935 \pm 491\end{array}$ \\
\hline Mentha & Common mint & $\mathrm{P}$ & May 24/Aug 28 & 96 & herb & 1,017 \\
\hline M. spp. ${ }^{3}$ & Peppermint ${ }^{3}$ & $\mathrm{P}$ & “ & “ & “ & $1,118 \pm 17$ \\
\hline M. X spicata & Spearmint & $\mathbf{P}$ & " & “ & “ & 1,386 \\
\hline Monarda didyma & $\begin{array}{l}\text { Panorama Mix } \\
\text { no designation }\end{array}$ & $\begin{array}{l}\mathbf{P} \\
\mathbf{P}\end{array}$ & $\begin{array}{c}\text { May 24/Oct } 1 \\
\text { “ }\end{array}$ & 130 & herb & $\begin{array}{c}1,011 \\
1,130 \pm 452\end{array}$ \\
\hline Nepeta cataria & no designation & $\mathbf{P}$ & May 28/Aug 27 & 91 & herb & $4,708 \pm 599$ \\
\hline Tanacetum parthenium & $\begin{array}{l}\text { White Wonder } \\
\text { Double Flowered } \\
\text { Single } \\
\text { Golden Ball } \\
\text { no designation }\end{array}$ & $\begin{array}{l}P \\
P \\
P \\
P \\
P\end{array}$ & $\begin{array}{c}\text { May } 24 / \text { Aug } 2 \\
\text { “ } \\
\text { May 24/July } 16 \\
\text { May 24/Aug } 2\end{array}$ & $\begin{array}{l}70 \\
. \\
. \\
53 \\
70\end{array}$ & $\begin{array}{l}\text { herb } \\
\text { "، } \\
\text { “" } \\
\text { "، } \\
\text { " }\end{array}$ & $\begin{array}{c}842 \\
776 \\
515 \\
105 \\
1,408 \pm 330\end{array}$ \\
\hline T. cinerarifolium & Pyrethrum & $\mathrm{P}$ & $"$ & “ & “ & 814 \\
\hline Valeriana officinalis & no designation & $\mathrm{P}$ & not harvested & - & sliced root & \\
\hline
\end{tabular}

1 These figures are based on averaging the yield values from each of the samples contained in the table row. See Table 2 for suppliers of each sample. SD = standard deviation.

2 Most calendula is sold as whole flower heads, calyx intact. The numbers in this table reflect petal weights with calyx removed, therefore actual yield can be expected to be higher.

3 Mentha $X$ piperita is a sterile hybrid, therefore seeds labelled as "Peppermint" are of an unknown species. 
Table 4. Prospective purchasers of fresh and dried herbs.

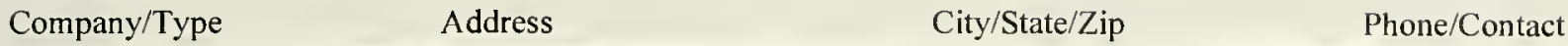

\section{RAW MATERIALS BROKERING/AGRICULTURAL CONSULTING}

Botanical Liaisons

1180 Crestmoor Drive

Boulder, CO 80303

303-494-1555

303-494-2555 fax

LARGE MANUFACTURERS

Attn: Trish Flaster

Nature's Herbs

600 East Quality Drive

American Fork, UT 84003

Murdock, Madaus, Schwabe

10 Mountain Springs Parkway

Springville, Utah 84663

Herb Pharm

PO Box 116

Williams, OR 97544

Attn. Ed Smith

Gaia

12 Lancaster County Road

Harvard, MA 01451

\section{LARGE RAW MATERIALS BROKERS}

Botanicals International 2550 El Presidio Street

Long Beach, CA 90810-1193

Frontier Coop

Box 299

Norway, IA 52318

Starwest

11253 Trade Center Drive

Rancho Cordova, CA 95742

\section{COST ANALYSIS RESEARCH}

New Mexico State University Dept. of Agriculural Economics and Business

Dept. 3169 Box 30003

Las Cruces, NM 88003

Dr. Connie Falk 


\section{Borago officinalis \\ (borage, burrage, common bugloss)}

\section{GERMINATION}

Borage was direct-seeded into the field on May 31. Observations of seed germination showed a small amount of sporadic failure.

\section{CROP YIELD (Figure 1)}

Borage is a rather vigorous annual with large fleshy stems and leaves. The entire plant was harvested at ground level, weighed and subsampled in the field. These subsamples were dried in the greenhouse and weighed again to calculate the percent moisture in the sample. This number was used to calculate the average wet and dry weights of the total crop. The $1.75-2 \mathrm{ft}$. spacing between plants was judged inadequate as those plants on the edges of the plot provided a higher yield (up to 144\%) than those in the center. A 2.5 $3 \mathrm{ft}$. square spacing may be more appropriate for this species to produce a greater yield per plant.

\section{MARKETABLE USES}

The fresh herb, high in potassium, is used in salads by many Europeans and the dried herb is used as a fever reducer and demulcent tea by herbalists (Dobelis, 1986; Medrano et al., 1992; Weiner, 1990). The bulk seed is processed for an oil rich in $\gamma$-linoleic acid which has shown evidence of reducing blood pressure (Engler et al., 1992). There may also be a limited market for the fresh or candied flowers for bake shops and gourmet stores.

\section{INSECTS/DISEASES}

There were no insect problems observed this season.

Borage is an excellent crop for anyone who also maintains a honey bee hive. Many members of the insect superfamily Apoidea (honey bees, carpenter bees, bumble bees) and the family Vespidae (yellow jackets and paper wasps) frequented the borage throughout the course of the summer. For this reason, harvesting was done outfitted with normal hive-operators clothing and apparatus.

An unidentified leaf spot was evident by the end of the season. While the disease did not appear to affect flowering, the foliar lesions were progressive and would have rendered most of the foliage unusable. Less watering and larger spacing may reduce the severity of this disease.

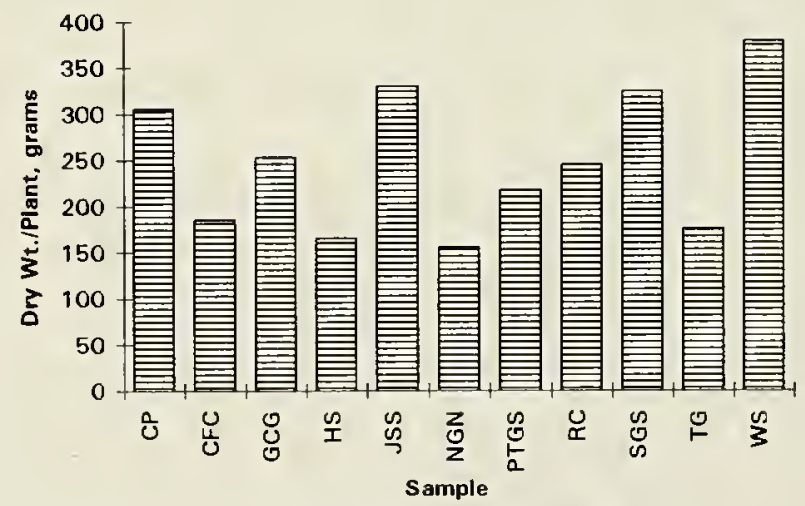

Fig. 1. Borago officinalis Yield 


\section{Calendula officinalis}

\section{(calendula, pot marigold, marybud, holigold)}

\section{GERMINATION (Figure 2)}

Seeds were sown in flats on April 1 under $1 / 4$ in. soil, misted with tap water, and placed under halogen lights in the greenhouse. Seeds germinated within 3 to 5 days of sowing. For most samples, maximum germination was reached within 9 days of sowing. Because of this relatively rapid germination, calendula should be planted indoors less than 3 weeks prior to potting up or transfer to a cold frame. They will quickly become leggy and chlorotic if left inside. Direct seeding is always a possibility after the danger of frost is past.

\section{CROP YIELD (Figure 3)}

Although some herbalists use calendula foliage, this study focused on the more commonly used flower heads and petals (Ody, 1994). One sample, Bon Bon Mix from NGN, began to develop buds as early as June 10 , and the first blossom opened on June 14. All other samples did not develop buds until June 21, blooming 5 days later. The first harvest occurred on June 28 when 6 of 9 samples had blossoms. The last sample to start blossoming was GCG on July 5. Thereafter, mature flower heads were harvested every 3 to 6 days, depending on the maturation rate of the blooms. Blooms were dried as described above, and the petals removed from the calyx prior to weighing. The average daily petal weight peaked between July 25 and August 5 with per plant petal weights as high as 8.11 grams (data not shown). Average per plant weights began to decrease at this point due to aster yellows, a phytoplasmamediated disease described below.

Yield per sample ranged from 215 to $617 \mathrm{lb}$. per acre. This difference is largely due to variation in flower type. Characteristics such as bloom size, rows of petals, and size of the disk flower portion of the bloom all added variation to the overall petal weight. Samples from CP, GCG, and SGS were internally uniform in shape and size while other samples showed much variation. Those from SGS were the only ones to have a single row of petals. The others, with double to multiple rows of white variegated to deep orange ray flowers and yellow to brown disk flowers, may have had higher yields due to the larger ray flower and petal number.

\section{MARKETABLE USES}

Calendula, containing triterpenoid saponins, is used topically as a principal component of antiseptic and anti-

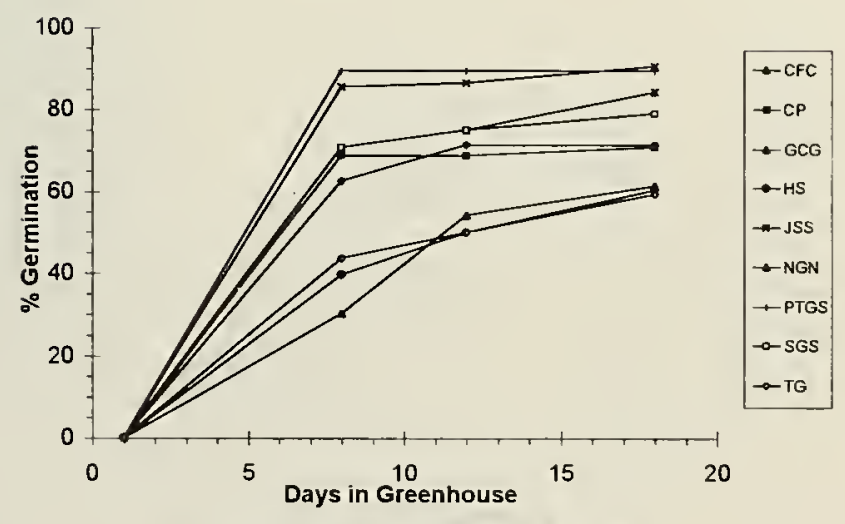

Fig. 2. Calendula officinalis Germ.

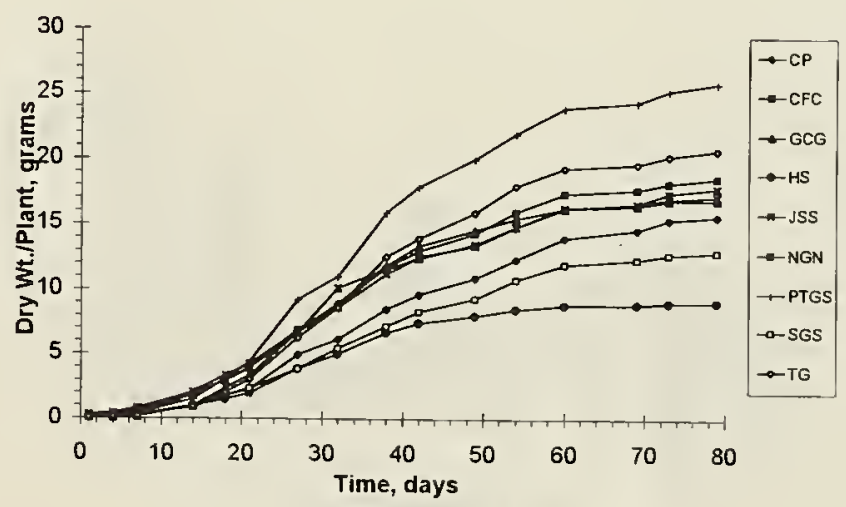

Fig. 3. Calendula officinalis Yield 


\section{Calendula officinalis (continued) (calendula, pot marigold, marybud, holigold)}

inflammatory creams or salves (Della-Logia et al., 1994; Weiner, 1990). The essential oil is an effective antifungal (Ody, 1993). Calendula petals are also used internally as a tea and as a garnish for salads and other dishes (Dobelis, 1986). The market price listed in Table 3 includes the calyx, which was removed prior to weighing in this study. Therefore, one could expect a higher yield than reported.

\section{INSECTS/DISEASES}

Two species of caterpillars damaged the calendula blooms. The damage occurred as the caterpillars burrowed into the center disk flowers, destroying ray flowers and calyx in the process. The most damage occurred, however, when the blooms were harvested. When the blooms were laid out to dry, caterpillars from infested blooms fed on surrounding blooms rendering the blooms unusable. This fact made harvesting more time consuming as caterpillar presence in the flower heads needed to be determined before picking. The tobacco budworm (Helicoverpa virescens) occurred in low numbers early in the harvest season. The sunflower moth (Homeosoma electellum), which appeared later in the season, did the most damage. In some cases, more than $1 / 2$ of the blooms in a harvest were infested.

There were also whiteflies (family Aleyrodidae) which were carried over from the greenhouse, and leaf hoppers (family Cicadellidae).

By far, the largest detriment to the calendula crop was aster yellows (proposed classification as a Phytoplasma spp.), a phytoplasma-mediated disease that alters the flower structure and renders flowers of Asteraceae and other plant families unusable. It is carried by leafhoppers, so control of the insect early in the season is critical. There is no known cure for aster yellows. If an infection is discovered early, the suspect plants should be pulled up and destroyed. Also, tools and hands should be cleaned with soapy water before handling other plants.

Powdery mildew (Erysiphe cichoracearum) infected plants until late in the season, but did not affect flower yield. 


\section{Echinacea purpurea and angustifolia (purple coneflower)}

\section{GERMINATION (Figure 4)}

Seeds for both $E$. purpurea and $E$. angustifolia were sown into flats on March 6, lightly covered with potting mix, watered, and wrapped in a plastic bag before being placed in a dark $40 \mathrm{~F}$ cold room. Flats were misted once per week and removed to the greenhouse after 12 days. The first seedlings of $E$. purpurea emerged after 5 days in the greenhouse. For most samples, maximum germination was reached after 11 days.

One sample of the notoriously difficult to germinate $E$. angustifolia seed was obtained. Only $19 \%$ germination was observed after $2 \mathrm{I}$ days in culture (data not shown).

\section{CROP YIELD (Figure 5)}

Some plants in all samples of E. purpurea flowered in the first year. The bolt stalks, with accompanying cauline leaves and terminal flowers, were harvested on October 1 , 130 days after planting out into the field. The variation in yield may be due to differences in the number of blooms per bolt stalk, the height of the bolt stalk, and number of bolt stalks per plant. The number of blooms per stalk varied widely, from a high of 23 to a low of 1 , with some plants not producing a bolt stalk at all. These latter plants were included in the yield per acre averages because they were viable and should produce bolt stalks next year.

The Echinacea genus is well known for the medicinal value of the root, which was not harvested this year. Normally 3 to 5 years are allowed for the root to develop before the entire plant is harvested.

None of the four surviving E. angustifolia seedlings flowered. Their growth was minimal, and no plants were. harvested.

\section{MARKETABLE USES}

Although the root of Echinacea is highly valued for its antiviral and immunostimulant properties (Bauer et al., 1988; Weiner, 1990), the aerial part of the plant also contains the active alkamide compounds and is used in teas (Bauer et al., 1989). Therefore, the bolt stalks will give some return on the initial investment until the roots develop sufficiently to be harvested.

\section{INSECTS/DISEASES}

Because Echinacea is a member of the aster family it is susceptible to the same insects and diseases as calendula and chamomile. Sunflower moth caterpillars were either present or there was evidence of their damage in greater than $80 \%$ (estimate) of blooms at harvest. This would render the blooms unusable for sale as a dried cut flower or to be ground for tea mixtures. No other pests or diseases were found on Echinacea.

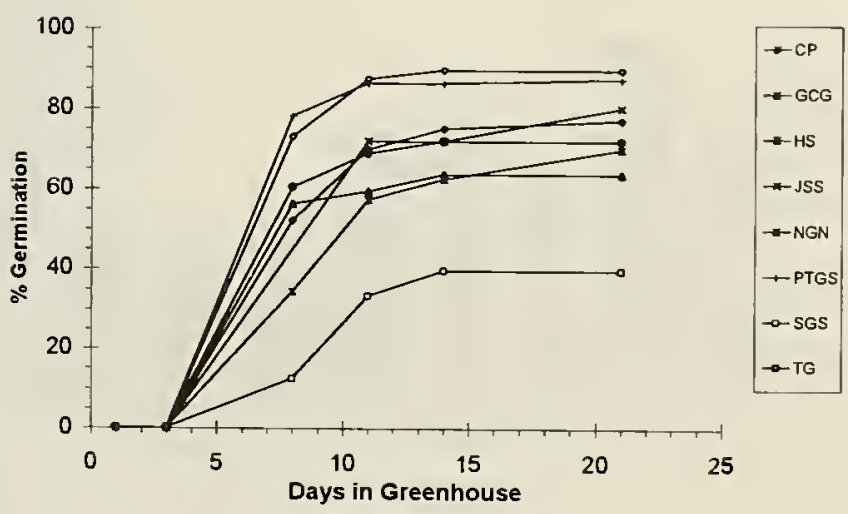

Fig. 4. Echinacea purpurea Germ.

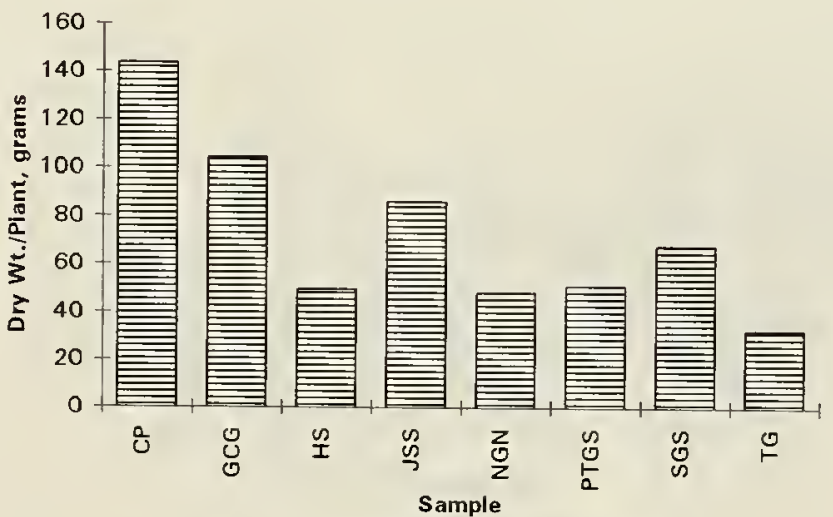

Fig. 5. Echinacea purpurea Yield 


\section{Hyssopus officinalis}

\section{(hyssop)}

\section{GERMINATION (Figure 6)}

Seeds were sown into flats on March 8 , barely covered with potting mix, and misted with water. The first of these seeds germinated within 3 days, and full germination was reached by day 11 .

\section{CROP YIELD (Figure 7)}

Hyssop was harvested on July 19, 53 days after planting out. Most plants were just beginning to flower. Herbaceous stems were cut $4-5$ in. above the soil line. Stems with leaves intact were dried in brown paper bags in a $45 \mathrm{C}$ oven. Although this species was harvested once this year, up to three harvests may be possible in future seasons.

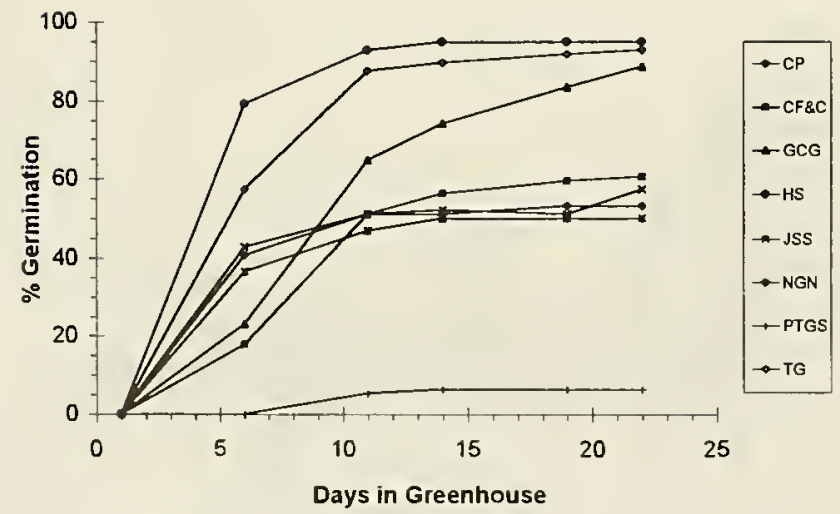

Fig. 6. Hyssopus officinalis Germ.

\section{MARKETABLE USES}

Hyssop, with its camphor-like fragrant leaves, is used medicinally as an expectorant and to soothe sore throats (Ody, 1993). A large number of monoterpenes are found in the foliage-derived essential oil, including pinocamphone, isopinocamphone, and limonene (Lawless, 1995). A polysaccharide from an aqueous extract of hyssop has shown activity against HIV-I in cell cultures (Gollapudi et al., 1995).

\section{INSECTS/DISEASES}

No pests or diseases were observed on hyssop.

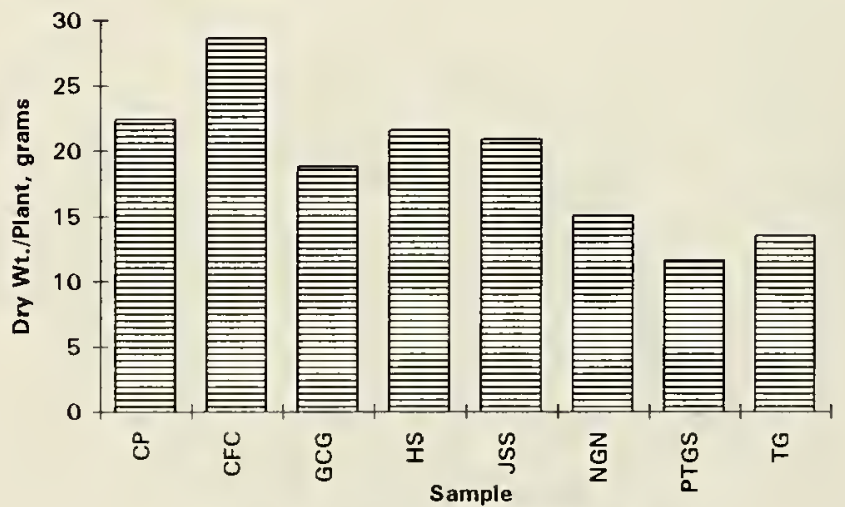

Fig. 7. Hyssopus officinalis Yield 


\section{Marrubium vulgare (horehound)}

\section{GERMINATION (Figure 8)}

Seeds were sown in flats on March 8, covered with $\mathrm{I} / 4$ in. fine soil, and misted with water. Germination began after 7 days, and most samples reached full germination percentage at about day 14 .

\section{CROP YIELD (Figure 9)}

Horehound, a member of the mint family, grows well in typical New England conditions. Plants were harvested on August 28, 96 days after transplanting seedlings into the field. The samples were well into bloom at harvest, and could have been harvested 2 weeks earlier. Only one harvest was made to allow plants to rejuvenate before winter. In future seasons it may be possible to have multiple harvests.

\section{MARKETABLE USES}

Horehound is commonly found in hard candies which are reported to have cold-soothing properties (Dobelis, 1986). The cut dried herb is also used in teas for the same purpose (Wiener, 1990).

\section{INSECTS/DISEASES}

Horehound was frequented by large numbers of bees. Detrimental insects were not detected. An unidentified disease that caused sporadic yellowing and subsequent necrosis of a small number of leaves on main stems did not reduce the harvest, as there were very few leaves affected.

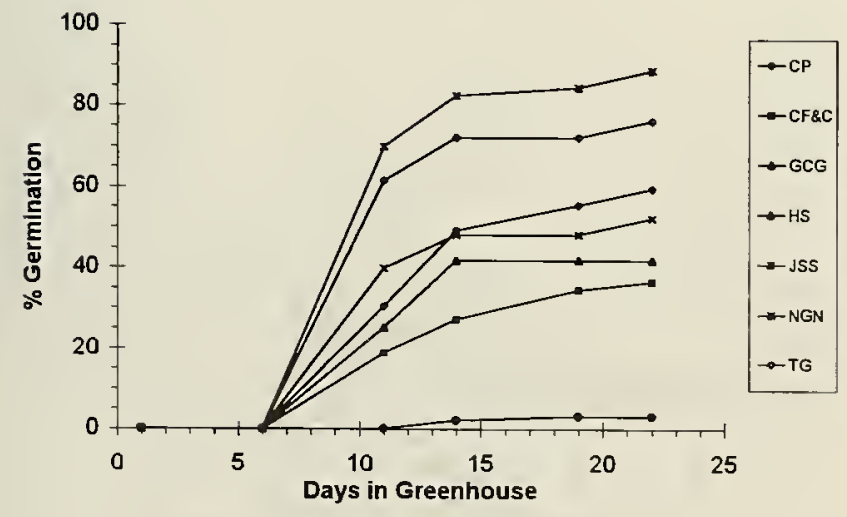

Fig. 8. Marrubium vulgare Germ.

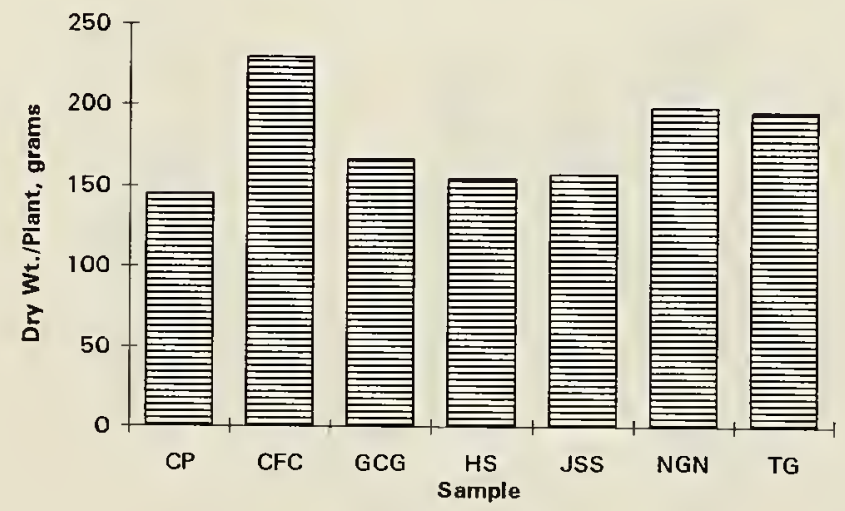

Fig. 9. Marrubium vulgare Yield 


\section{Matricaria recutita \\ (German or Hungarian chamomile)}

\section{GERMINATION}

Chamomile was direct seeded into the field on May 29 and 30. Seeds from NGN did not germinate at all over the course of the entire season. Seeds from PTGS generated 45 plants. The average was 15.3 plants per seed package, all seeds in the package being sown. Samples were thinned to a maximum of 10 plants as the first flowers began to bloom.

\section{CROP YIELD (Figure I0)}

Flower heads from chamomile were harvested at 3-7 day intervals during the season. The last harvest occurred on September 16, 105 days after sowing. Samples segregated into two different growth habits: 1) tall, somewhat leggy stems with sparse, large blooms (CP, GCG, JSS, RC, SGS, and TG); and 2) short, compact stems with dense, small blooms (CFC, HS, and PTGS). Because chamomile flowers need to be picked by hand for a high-quality product, the taller samples with the large blooms were much easier to harvest than their shorter counterparts. However, the yield from the low growing varieties (753 Jb. per acre) was 105\% greater than that for the tall $(367 \mathrm{lb}$. per acre).

\section{MARKETABLE USES}

Chamomile is known for its sedative and antispasmodic effects because of its high content of azulene (Lawless, 1995; Weiner, 1990). It is currently produced in high quantities and good quality in Mexico and Egypt where labor is inexpensive. This makes it virtually impossible for growers in Connecticut to compete on the open market. However, a small plot grown under organic practices for local sale could prove profitable if labor costs are kept to a minimum.

\section{INSECTS/DISEASES}

Chamomile is a member of the aster family and is susceptible to similar pests and diseases as calendula. The sunflower moth was present in moderate numbers, as well as powdery mildew and aster yellows.

A variety of other insects were observed on chamomile. These included lady beetles (family Coccinellidae), soldier beetles (Chauliognathus pennsylvanicus), and various types of bees. Aphids (family Aphididae) were also found on some roots.

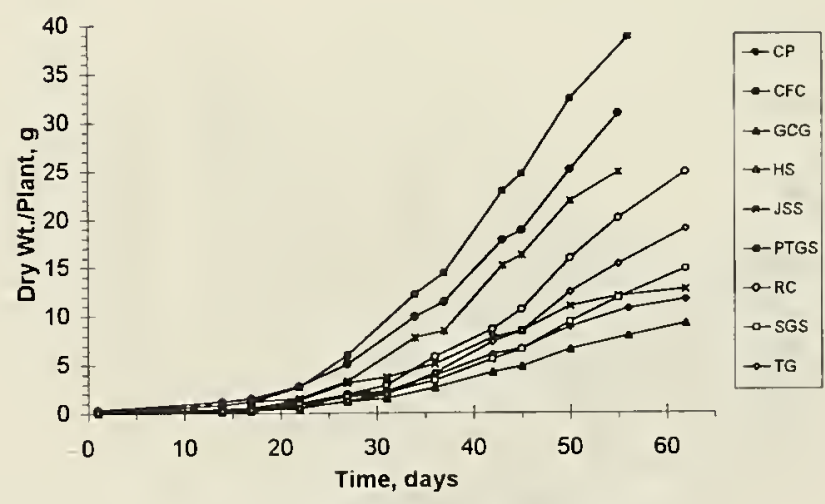

Fig. 10. Matricaria recutita Yield 


\section{Melissa officinalis}

\section{(lemon balm, balm, or melissa)}

\section{GERMINATION (Figure 11)}

Seeds were sown on March 6 onto the surface of wet potting mix and misted with water. Flats were placed under halogen lights in the greenhouse. Lemon balm was one of the slower and more sporadic germinators of the seeds tested. Low germination was recorded after 8 days. Significant germination was observed after 13 days in 3 of 7 samples.

\section{CROP YIELD (Figure 12)}

Lemon balm did not flower in 1996. Harvest was completed late in the season, leaving enough time for the plants to rejuvenate before winter. This resulted in a uniform mix of herbage. The high standard deviation in Table 3 may have been caused in part by differences in growth habit between samples. The TG and CFC samples tended to be low and spreading, with lower yields, while the rest of the samples had more upright growth (data not shown).

\section{MARKETABLE USES}

Lemon balm is used as a filler for many medicinal tea mixes. It helps to hide unpleasant flavors while adding a general fever-reducing and anti-depressant action (Ody, 1993; Weiner, 1990). Externally, it is used on skin eruptions and as an insect repellent (Greive, 1992; Lawless, 1995).

\section{NSECTS/DISEASES}

An unidentified necrosis affected a few of the plants not sampled for this study. The necrosis was similar to that reported above for horehound, but more severe, affecting the centermost stems and leaves. Symptoms began as a purpling of the leaves, then quickly progressed to yellowing and death of entire stems. Foliage on the perimeter of the plant was not affected.

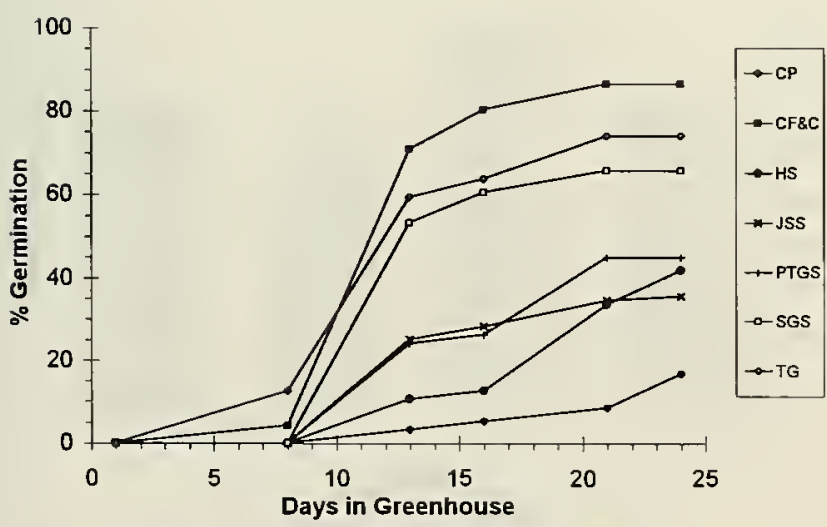

Fig. 11. Melissa officinalis Germ.

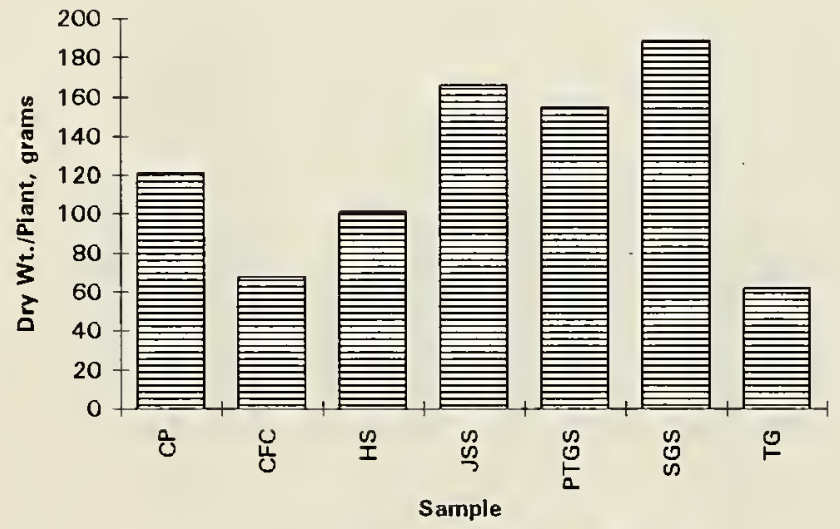

Fig. 12. Melissa officinalis Yield 


\section{Mentha species}

\section{(mint)}

\section{GERMINATION}

Peppermint is actually a $99 \%$ sterile hybrid that is normally reproduced from cuttings (Tucker, 1993). Other mints, such as $M$. $x$ spicata, do produce seed, but the resulting plants are usually inferior. The only true description of mint seed came from PTGS, whose package was labeled "common mint". The seed catalog instructions suggested to plant the entire package of seed and select a few of the best plants for the garden. If true peppermint and spearmint are desired, cuttings can be obtained from reputable sources.

Mint seeds are extremely small and difficult to handle. No quantitative analysis of germination was made; however, seed germination appeared to be excellent. Seeds were sown on April I onto wet potting mix in flats and barely covered with soil. The flats received ambient greenhouse light. Seedlings were thinned heavily after 28 days. Remaining seedlings were directly transferred to the field from flats after another 3 weeks in the greenhouse.

\section{CROP YIELD (Figure I3)}

The various mints are similar in their growth habits and therefore produced similar yields. Some sporadic flowering was observed toward the end of the season, and plants were harvested shortly thereafter (on August 28), 96 days after planting out into the field.

\section{MARKETABLE USES}

Both peppermint and spearmint are common flavoring agents in a wide variety of household products, especially those used in oral hygiene and for cold and flu treatment. Both are also known for their digestion-settling properties (Erichen-Brown, 1979, Weiner, 1990). The principal component of peppermint is menthol, a volatile monoterpene (Lawless, 1995). Spearmint contains less menthol but has high levels of carvone, a related compound (Lawless, 1995). In addition to the dried product, sales of the fresh herb to manufacturers of essential oils may also provide income.

\section{INSECTS/DISEASES}

Mints are generally hardy, vigorous growers and quick spreaders. lsolated plants showed a similar type of leaf necrosis and decline as the horehound and lemon balm. The causative agent is currently unknown.

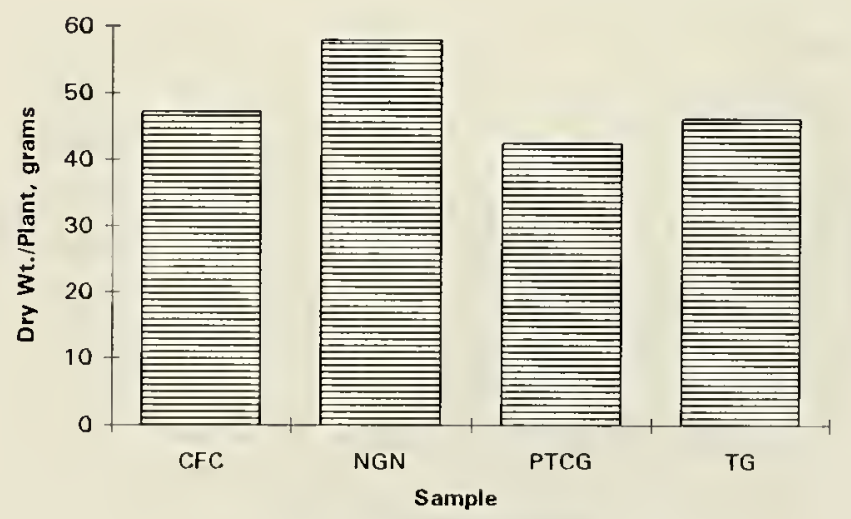

Fig. 13. Mentha Species Yield 


\section{Monarda didyma}

\section{(bee balm, bergamot, Oswego tea)}

\section{GERMINATION (Figure 14)}

Seeds were sown into wet potting mix in flats on March 6 , lightly covered with soil, misted with water, and placed under halogen lights in the greenhouse. The first seedlings began to emerge after 8 days, with the germination rate leveling off after 16 days. As Figure 14 shows, there were large differences between the percent germination in this species, ranging from $93 \%$ to no germination at all.

\section{CROP YIELD (Figure 15)}

Bee balm did not flower in 1996. This fact allowed for a longer growing season (130 days) as foliage is normally harvested as the plants begin to bloom. Instead, plants were cut with hedge clippers 5-6 in. above the soil line approximately 2 weeks before the first projected frost date.

\section{MARKETABLE USES}

Both the foliage and flowers of Bee Balm are marketable. The foliage, cut and dried, is used as a tea to aid in digestion and for respiratory ailments (Erichsen-Brown, 1979, Grieve, 1992). Thymol, an active compound in Monardas, is a powerful antiseptic for both internal and external use (Grieve, 1992). The showy blooms of $M$. didyma can be used as cut-flowers in arrangements and bouquets.

\section{INSECTS/DISEASES}

Although no insect pests were observed on Monarda, there were two diseases which may have been enhanced by a high amount of rainfall. The first was powdery mildew (Erysiphe spp.), a common problem on Monardas grown for ornamental use. The second disease was more difficult to pinpoint. At mid-season the lower leaves of some plants developed black necrotic spots which progressed slowly into a yellowing of the leaf and eventual leaf drop. Leaf spot has been reported on Monarda, usually during periods of high moisture.

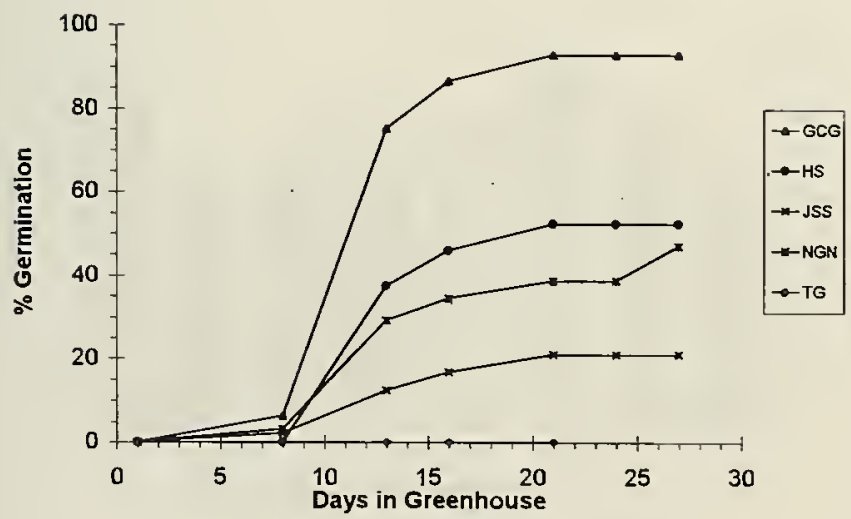

Fig. 14. Monarda didyma Germ.

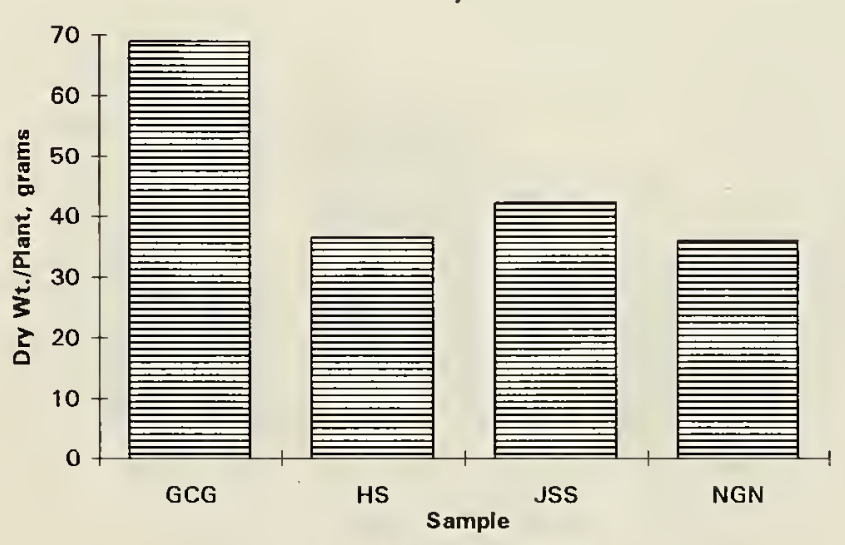

Fig. 15. Monarda didyma Yield 


\section{Nepeta cataria}

\section{(catnip)}

\section{GERMINATION (Figure 16)}

Catnip has been called a weed by many gardeners. However, the relatively high germination rates normally associated with weedy species were not evident in this trial. Seeds were sown in flats on March 7 onto wet potting mix and lightly covered with soil. The flats were misted with water and placed in ambient lighting in the greenhouse. The first seedlings began to emerge after 7 days, and germination rate leveled off after 20 days, rather late compared to other species.

\section{CROP YIELD (Figure I7)}

Catnip grew vigorously. The initial leggy stems, some almost $2 \mathrm{ft}$. tall, were clipped shortly after transplanting into the field to encourage bushier growth. After 91 days in the field, all plants were in full flower with seed set occurring on the larger specimens. The $2 \mathrm{ft}$. spacing between plants may not have been sufficient, as the central plants appeared more leggy than those on the edges of the plot. Increasing the spacing to $3 \mathrm{ft}$. may encourage fuller growth and higher yields.

\section{MARKETABLE USES}

Catnip has been used traditionally as a sedative and as an aid in respiratory ailments and stomach pains (Dobelis, 1986; Greive, 1992, Weiner, 1990). It contains nepetalactones, a class of volatile monoterpene compounds with antiseptic properties (Bourrel, I993). Most common preparations use the dried leaves and herbaceous stems in tea.

\section{INSECTS/DISEASES}

No pest or disease problems were associated with catnip. However, various types of bees were abundant.

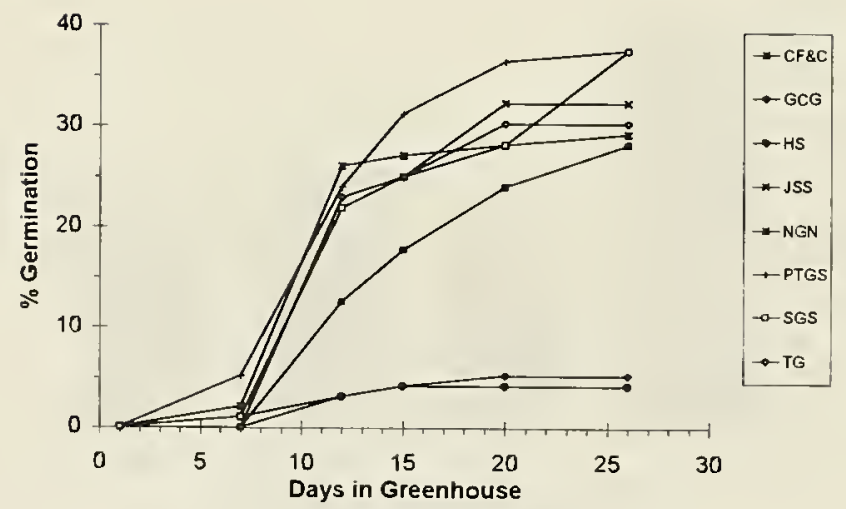

Fig. 16. Nepeta cataria Germination

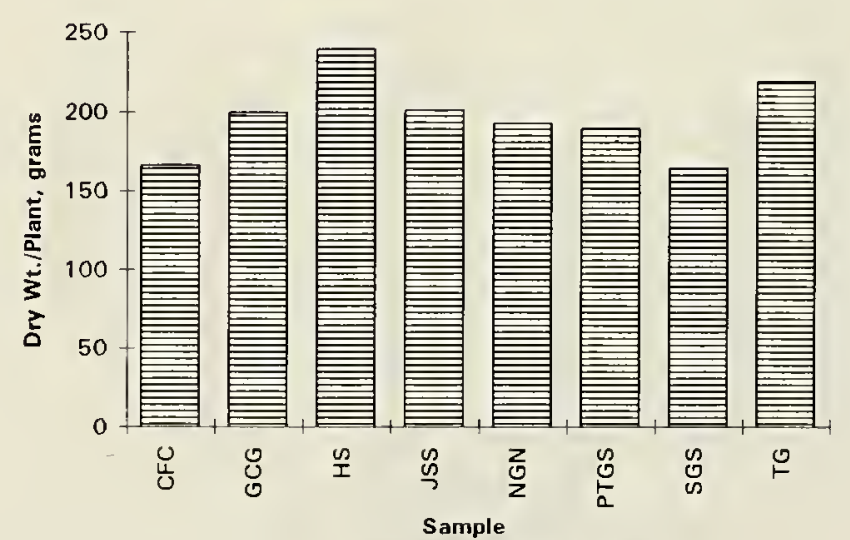

Fig. 17. Nepeta cataria Yield 


\section{Tanacetum parthenium \\ (feverfew) \\ Tanacetum cinerarifolium \\ (pyrethrum)}

\section{GERMINATION (Figure 18)}

Feverfew seeds were sown on March 7 into moist potting soil, barely covered with soil, and placed under halogen lights in the greenhouse. The first seedlings began to emerge in 3 days, with the percentage leveling off at day 12 .

\section{CROP YIELD (Figure 19)}

Samples of feverfew arrived with various Latin names. The aster family has undergone some major changes in classification during the last few years, and labels have not kept up with the latest nomenclature. The current Latin name for feverfew is Tanacetum parthenium. However, packages were labeled Chrysanthemum parthenium and Matricaria parthenium, both older synonyms for feverfew. One company (GCG) sent seeds of pyrethrum (Tanacetum cinerarifolium) in addition to feverfew. Name changes not withstanding, there was a large variation in yield between samples. The lowest yield came from Golden Ball (PTGS), which is cultivated more for omamental rather than medicinal use. Its short stature (under $2 \mathrm{ft}$.) left little room for foliage. Other samples, divided into single flowered (yellow disk flowers and white rays) and double flowered (few yellow rays in center of head, rest white rays), produced much more foliage on a 2-3 ft. high plant. The pyrethrum sample from GCG was also double flowered. The single flowered varieties averaged $1,267 \mathrm{lb}$. per acre $\pm 39 \mathrm{I}$ $\mathrm{lb}$. and the double $646 \mathrm{lb}$. per acre $\pm 185 \mathrm{lb}$. (data not included Table 3 ). The $2 \mathrm{ft}$. spacing worked well for this species.

\section{MARKETABLE USES}

Feverfew is one of the many herbs that are making the crossover from traditional herbalism to mainstream medicine. Parthenolides, a class of sesquiterpene lactones found in the flowers and foliage, have been shown to reduce the incidence and severity of migraine headaches (Ody, 1993; Voyno-Yasenetskaya, 1988; Weiner, 1990). For these reasons, the demand for feverfew is predicted to increase.

\section{INSECTS/DISEASES}

There were no pest or disease problems associated with feverfew.

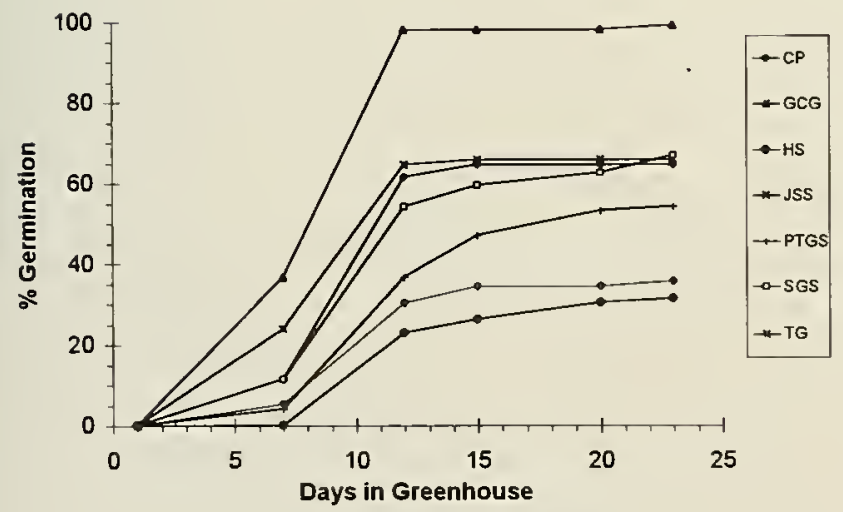

Fig.18. T. parthenium Germ.

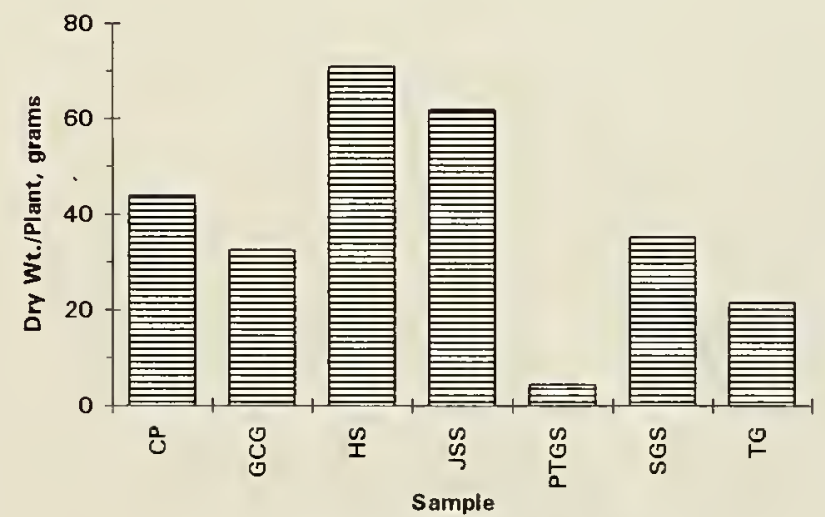

Fig. 19. T. parthenium Yield 


\section{Valeriana officinalis}

(valerian)

\section{GERMINATION (Figure 20)}

Valerian seeds were subjected to a cold treatment in a similar manner to the Echinacea. Seeds were sown on March 6 in moist potting mix and covered with $1 / 4-1 / 2$ in. soil. Flats were wrapped in plastic and placed in a dark $40 \mathrm{~F}$ cold room. After 6 days they were removed to the greenhouse and placed under halogen lights. Cotyledons first became visible 5 days after transfer, with germination plateauing after 10 days for all but one seed lot (HS).

\section{CROP YIELD}

The medicinally useful root needs 3-5 years to mature and therefore was not harvested. The herbage is not used medicinally.

\section{MARKETABLE USES}

Valerian contains valepotriates, a class of compounds known to have sedative and tranquilizing properties (Weiner, 1990). Demand for this root is projected to increase as clinical trials for its use in the treatment of insomnia and depression progress.

\section{INSECTS/DISEASES}

No pest or disease problems were found associated with valerian.

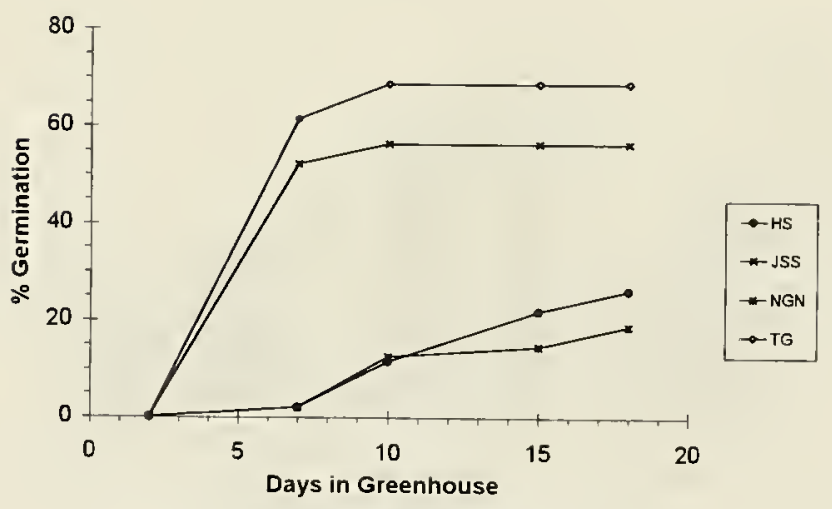

Fig. 20. Valeriana officinalis Germ. 


\section{REFERENCES}

Anonymous. 1995. "Medicinal Herbs Market." (c) New Hope Communications, Boulder, $\mathrm{CO}$.

Bauer, R., Jurcic, K., Puhlmann, J., and Wagner, H. 1988. Immunological in vivo examinations of Echinacea extracts. Arzneim-Forsch, 38(2):276-281.

Bauer, R., Remiger, P., and Wagner, H. 1989. Alkamides from the roots of Echinacea angustifolia. Phytochemistry 28(2):505-508.

Bourrel, C., Perineau, F., Michel, G., Bessiere, J. M. 1993. Catnip (Nepeta cataria L.) essential oil: analysis of chemical constituents, bateriostatic and fungistatic properties. J. Essent. Oil Res. 5(2):159-167.

Della-Loggia, R., Tubaro, A., Sosa, S., Becker, H., St-Sarr., and Issac, O. 1994. The role of triterpenoids in the topical anti-inflammatory activity of Calendula officinalis flowers. Planta Med. 60(6):516-520.

Dobelis, 1. N., ed. 1986. Magic and Medicine of Plants. Reader's Digest Association, lnc. USA. 484 p.

Emerich, M. 1996. "Industry Growth: 22.6\%." Natural Foods Merchandiser, June 1996, (c) New Hope Communications, Boulder, $\mathrm{CO}$.

Engler, M. M., Engler, M. B., and Paul, S. M. 1992. Effects of dietary borage oil rich in gamma-linoleic acid on blood pressure and vascular reactivity. Nutr. Res. 12(4/5):519-528.

Erichsen-Brown, C. 1979. Medicinal and Other Uses of North American Plants. Dover Publications, Inc. New York, NY. 512 p.

"Farm Numbers and Land in Farms". 1996. National Agricultural Statistics Service, United States Department of Agriculture. Washington, DC.
Gollapudi, S., Sharma, H. A., Aggarwal, S., Byers, L. D., Ensley, G. E., Chabard, J. L. 1995. Isolation of a previously unidentified polysaccharide (MAR-10) from Hyssop officinalis that exhibits strong activity against human immunodeficiency virus type 1. Biochem. Biophys. Res. Commun. 210(1):151-154.

Grieve, M. 1992. A Modern Herbal. Dorset Press. Great Britain. $912 \mathrm{p}$.

Hoagland, D.R. and Arnon, D.1. 1950. The water culture method for growing plants without soil. Univ. Calif. Agric. Expt. Stn. Cir., No. 347.

Lawless, J. 1995. The 1llustrated Encyclopedia of Essential Oils. Barnes and Noble Books. New York, NY. 256 p.

Medrano, A., Masoud, T. A., and Martinez, M. C. 1992. Mineral and proximate composition of borage. J. Food Compos. Anal. 5(4):313-318.

Mergentime, K. and Emerich, M. 1996. "Widening Market Carries Organic Sales to $\$ 2.8$ Billion in 1995." Natural Foods Merchandiser, June 1996, (c) New Hope Communications, Boulder, $\mathrm{CO}$.

Ody, P. 1993. The Complete Medicinal Herbal. Dorling Kindersley. New York, NY. 192 p.

Tucker, A. O. 1993. Is this plant a hoax? A lecture in honor of Otto Richter. in Proceedings of Herbs '93: The Eighth Annual Herb Growing and Marketing Conference, July 8-11, Bellevue, WA.: The International Herb Growers and Marketers Association, Mundelein, 11l. p. 177-183.

Voyno-Yasenetskaya, T.A. 1988. Effects of an extract of feverfew on endothelial cell integrity and on cAMP in rabbit perfused aorta. J. Pharm. Pharmacol. 40:501.

Weiner, M.A. 1990. Weiner's Herbal: The Guide to Herb Medicine, 2nd ed. Quantum Books. Mill Valley, CA. $284 \mathrm{p}$. 

University of

Connecticut

Libraries

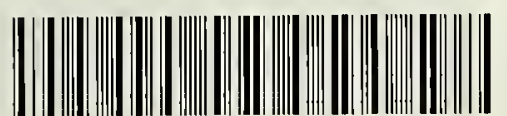

39153029109305 



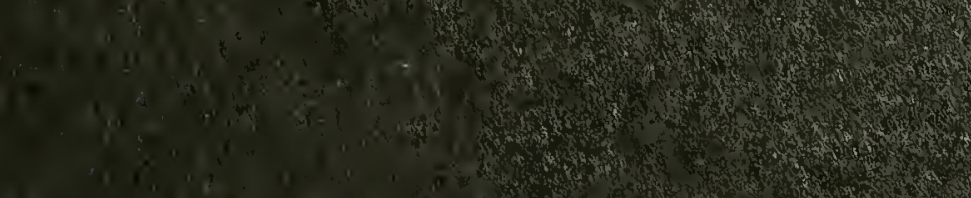

6.

201
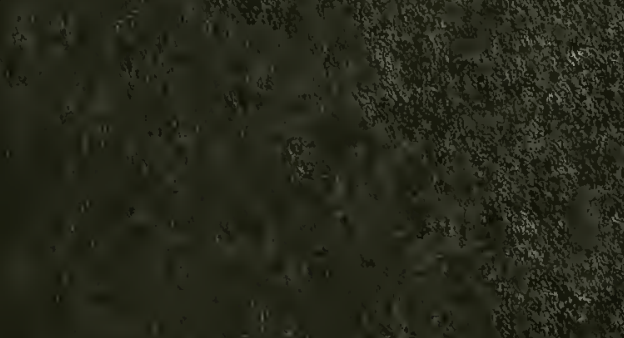

(n)

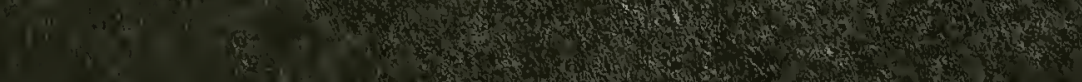


